\title{
Ovarian Cancer pT1c TNM Finding v6
}

National Cancer Institute

\section{Source}

National Cancer Institute. Ovarian Cancer pT1C TNM Finding v6. NCI Thesaurus. Code C60907.

Ovarian cancer involving one or both ovaries with either a ruptured capsule, or tumor on the ovarian surface, or presence of malignant cells in either ascites or peritoneal washings. (from AJCC 6th Ed.) 